研究助成
成果報告 Hosokawa Powder Technology Foundation ANNUAL REPORT

14109

\title{
粒子混相流におけるコヒーレント熱輸送システムの創出 \\ Study of Heat Transfer Mechanism with Coherent Flow Structure in Particle-dispersed Two-phase Flow
}

\author{
研究代表者 Research leader：竹内 伸太郎 Shintato TAKEUCHI \\ 大阪大学大学院工学研究科 准教授 \\ Graduate school of Engineering, Osaka University, Associate Professor \\ E-mail: shintaro.takeuchi@mech.eng.osaka-u.ac.jp
}

\begin{abstract}
抄録
有限サイズ粒子を含む流れの中における特徵的な粒子運動およびそれに伴う熱輸送に対する効果の モデリングに対する研究を実施した，物性の異なる粒子と周囲流体の界面における熱輸送を Euler 系で解く方法を発展させて粒子間の接触伝熱を解析する手法を提案した．粒子運動に伴う熱輸送に ついて解析するため高濃度粒子混相中の熱輸送解析へ適用し, 粒子数密度が高い領域で複数の粒子 間を接触面を介して伝熱する様子を確かめ, そこでの熱伝達モードの貢献を調べた。 また，いくつ かのレイリー数, 粒子数密度および粒子熱伝導率の組み合わせの場合に, 粒子による熱輸送のうち 伝導と対流による貢献を調べたところ, 粒子数密度および粒子熱伝導率に依存して主要熱伝達モー ドの遷移が顕れ，それに伴って特徵的な粒子運動が発生していることを見出した。
\end{abstract}

\begin{abstract}
Heat transfer problem in solid-dispersed two-phase flow is numerically studied. Temperature gradient within the finite-sized particles and inter-particle heat flux due to collisions are considered, and those effects on the flow structure and heat transfer are discussed. The interfacial flux model is extended to incorporate the heat conduction due to inter-particle contacts, based on 2-D and axisymmetric contact heat resistance solutions. The method is applied to 2-D and 3-D natural convection problems including multiple particles in a confined domain. Under high solid volume fraction conditions, the particles are observed to form densely concentrated regions, where heat flow tends to channel through the contacting points. In three-dimensional solid-dispersed flows, by decomposing the heat flux into the contributions of the convection and conduction, the change of the major heat transfer mode is studied for different solid volume fractions and conductivity ratios.
\end{abstract}

研究背景と目的

本助成では, 有限サイズ粒子を含む流れの中
における特徵的な粒子運動およびその熱輸送に 対する効果のモデリングに対する基礎的な研究 を実施した，報告者は，有限サイズ粒子を含む 
混相流において粒子内の温度分布を考慮した混 相媒体内熱輸送の数值解析を行うことにより, 粒子と流体の熱伝導率比に依存して新奇な集団 的運動モードが発生することを見出した ${ }^{[1]}$.ま たその運動を粒子内部と周囲流体の熱輸送にか かる時間スケールの比で説明し, 有限サイズ粒 子に損いて粒子内部の温度分布を考慮すること の重要性を指摘した。本助成ではモデル化を推 し進め, 粒子間の接触伝熱を考慮した粒子混相 中の熱輸送解析を実施し, 粒子運動に伴う熱輸 送について解析を行った。粒子が緩やかに運動 する状態から激しく運動する系までパラメー ターを変化させ, いくつかのレイリー数, 粒子 体積率および粒子熱伝導率の組み合わせの場合 に，粒子による熱輸送のうち伝導と対流による 貢献を調べた。

\section{研究 方 法}

数值計算では相対運動する粒子による流れお よび熱輸送を取り扱うため, 直交等間隔格子を 用い, 粒子の一直径を 10 以上の流体格子を用 いて離散化を行う。

流体セルの一部分が粒子によって占められる 場合（界面セル）に抏いて，界面に扔ける熱流 束を数值的に与える式 ${ }^{[1],[2]}$ を一般化し, 以下 の式によって粒子間接触熱流束 $q^{C}$ を提案した：

$$
\begin{aligned}
-\left.\boldsymbol{q}^{\mathrm{C}}\right|_{i, j, k}= & \left.\left.\lambda_{h}^{C}(\boldsymbol{n n})\right|_{i, j, k} \cdot \nabla T\right|_{i, j, k} \\
& +\left.\left.\lambda_{a}^{C}(\boldsymbol{I}-\boldsymbol{n n})\right|_{i, j, k} \cdot \nabla T\right|_{i, j, k}
\end{aligned}
$$

ここで $n$ はセル（インデックス $i, j, k)$ にお いて粒子から流体へ向かう単位法線ベクトル, $\nabla T$ は局所温度勾配, $\lambda_{h}^{C}$ と $\lambda_{a}^{C}$ はそれぞれ法線方 向と接線方向の見かけの熱伝導率で, 固体粒子 の熱伝導率 $\lambda_{S}$ を用いて以下のように与えられ る:

$$
\lambda_{h}^{C}=\left(1-\frac{2 z_{1}}{\delta}+\frac{\ell_{R}}{\delta}\right)^{-1} \lambda_{s}, \quad \lambda_{a}^{C}=\left(1-\frac{2 z_{1}}{\delta}\right) \lambda_{s}
$$

ただし $\ell_{R}$ は次式

$$
\frac{\ell_{R}}{r_{2}}=2\left(\frac{D_{1}}{D_{2}}+\frac{z_{1}}{r_{2}}\right)
$$

で与えられる接触熱抵抗の等価長さである。ま た $\delta, z_{1}, z_{2}$ は粒子間接触部を模擬した系の形 状パラメーター, $D_{0}, D_{1}$ は粒子間接触部を模 擬した系の熱伝導方程式の解を基本解 (二次元 では三角関数群，三次元ではベッセル関数群） に分解した際に現れる係数行列式である。なお 係数行列式は非常に複雑な式であるため, 詳細

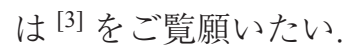

式（1）～（3）の独創的な点は, 二次元 · 三 次元を問わず球形あるいは円形の粒子間接触に よる熱流束モデルを, 粒子間接触のない場合に おける流体・固体界面での熱流束を与える式 [1][2] と同じ形式にまとめることができたことであ り，それにより粒子混相流内の熱伝導モデルを 統一的に記述することを可能にした。

\section{研 究成 果}

図 1 に, 粒子間接触伝熱を考慮した二次元粒 子混相流れにおける速度場と温度場のスナップ ショット，および同じ時刻に扔ける熱流束のべ クトルを示す。ここでは重力は図の下向きに作 用して抢り, 正方の計算領域の下面は高温, 上 面は低温になるように一定の温度差が維持され ることで自然対流が発生する。また側面は断熱 されている。レイリー数は $10^{5}$ とし，流体との 熱伝導率比が $5 \times 10^{2}$ となる粒子を体積率 $50 \%$ で含む. 図 1 (a) より分かるとおり, 粒子と 流体の時計方向への回転に伴い, 正方領域の右 上と左下に局所的に粒子の存在率が高い領域が 発生する。それらの領域では粒子が高温壁また は低温壁へ向かって数珠状に配置すると（図 1 （b）極めて強い粒子間の熱伝導が発生する. すなわち, 図の右上領域（吹き上げ領域）では 下壁付近で温められた粒子からすでに上壁付近 にいる粒子に対して，また左下領域（吹き降ろ し領域）では上壁付近で冷やされた粒子と下壁 付近にいる粒子の間で, 複数粒子にわたって卓 越した熱輸送が発達する。

図 2 には, 三次元に扔ける大規模な粒子混相 流の内部の温度分布を示す.上の例と同様に, 


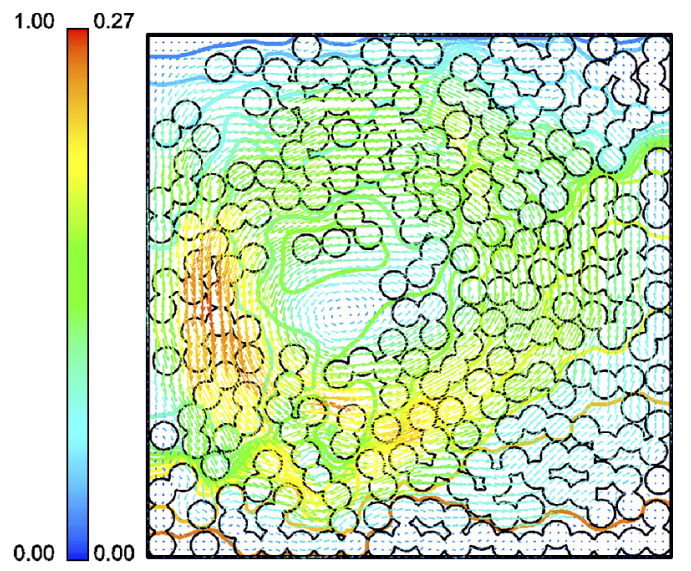

(a) Velocity field

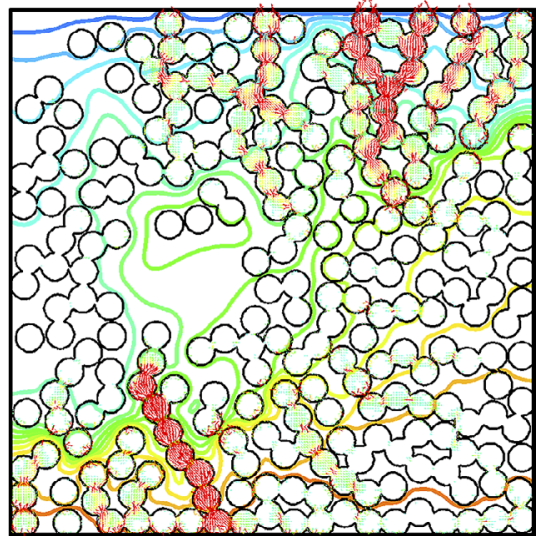

(b) Conductive heat flux

Fig. 1 Reproduced from Ref. [3]. Instantaneous flow field and heat flux at Rayleigh number $10^{6}$ for the Young's modulus $E_{p}=10^{7}$ after reaching quasisteady state (at $t=1000$ ). Bulk solid volume fraction is $50.3 \%$. (a) Velocity and temperature fields. (b) Heat flux vectors (arrows) at the same instance as (a). The density ratio is $\rho_{s} / \rho_{f}=1.005$. The isothermal lines are drawn at constant intervals.

図中の下方向に重力が作用し，下面と上面の間 に一定温度を維持する自然対流系でレイリー数 を $10^{6}$ とし，体積率が約 $35 \%$ になるように粒 子を入れた。粒子と流体の熱伝導率比が $10^{0}$ と $10^{2}$ のつのケースについて調べた。前者では （後者にくらべて）粒子内部の熱伝導がゆっく りであるため，下壁（高温壁）および上壁（低 温壁）の付近にいる粒子には, 粒子表面ではっ きりとした温度分布が見られるのが特徵であ る。粒子数を変化させたところ，ある值までは

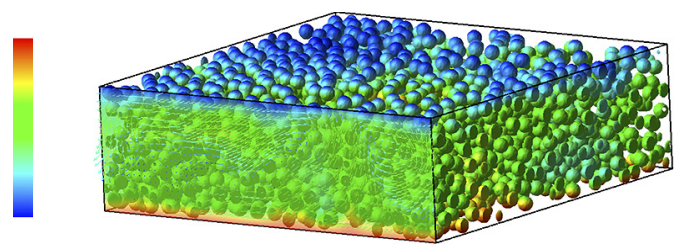

(a) $\lambda_{s} / \lambda_{f}=10^{0}$

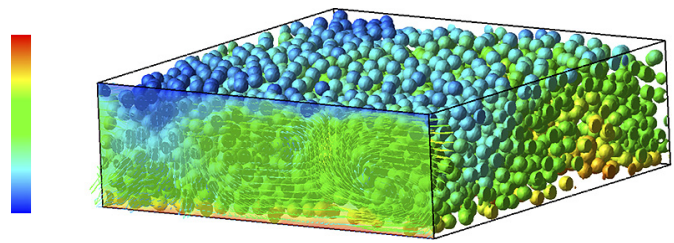

(b) $\lambda_{s} / \lambda_{f}=10^{2}$

Fig. 2 Reproduced from Ref. [3]. Instantaneous flow fields $(t=800)$ visualised by velocity vectors (in a vertical face of the domain) and local surface temperature of particles of conductivity ratios (a) $\lambda_{s} / \lambda_{f}=10^{0}$ and (b) $\lambda_{s} / \lambda_{f}=10^{2}$. A total of 3087 particles are employed for each case.

系の熱輸送は粒子数密度と正の相関をもつが, 粒子数をさらに増やして対流による熱輸送が抑 制されるに伴い, 特徴的な粒子運動の波動現象 が見られた。 また，粒子運動が激しい条件下で は, 系に印加した温度勾配とは逆の平均温度勾 配が発生する領域が発生する。これは有限サイ ズ粒子がもつ粒子内熱伝導性によって速度場と 温度場に非相似性が顕れた例と考えられ, 現在 はこの問題の解析を進めている段階である.

また, 本助成の研究対象ではないが, 助成対 象から着想を得て実施された関連研究として以 下の成果を挙げる：

・粒子混相流中の熱輸送問題に用いた数值解析 法に対してさらに一般化・高精度化を行い, 物体界面に拈ける速度場・圧力場および温度 場の離散化の整合性を考慮した高精度な熱流 体解析手法への発展 ${ }^{[4]}$.

・粒子を伴わない流体単相の系ではあるが, 循 環流れを利用した熱輸送機器の特性解析 ${ }^{[5]}$. ・粒子に働く流体力のモデリング [6][7]. 


\section{参考文献}

[1] Takeuchi, S., Tsutsumi, T. and Kajishima, T., "Effect of temperature gradient within a solid particle on the rotation and oscillation modes in solid-dispersed two-phase flows", International Journal of Heat and Fluid Flow Vol. 43, pp. 15-25 (October 2013).

[2] Tsutsumi, T., Takeuchi, S. and Kajishima, T., "Heat transfer and particle behaviours in dispersed two-phase flow with different heat conductivities for liquid and solid", Flow, Turbulence and Combustion Vol. 92, Issue 1-2, pp. 103-119 (January 2014).

[3] Takeuchi, S., Tsutsumi, T., Kondo, K., Harada, T. and Kajishima, T., "Heat transfer in natural convection with finite-sized particles considering thermal conductance due to inter-particle contacts", Computational Thermal Sciences Vol. 7, Issue 5-6, pp. 385-404 (2015, Available online on 28 Jun., 2016).

[4] Sato, N., Takeuchi, S., Kajishima, T., Inagaki, M. and

\section{学術論文}

1. Toshiaki Fukada, Shintaro Takeuchi and Takeo Kajishima, "Interaction force and residual stress models for volume-averaged momentum equation for flow laden with particles of comparable diameter to Kolmogorov length scale", International Journal of Multiphase Flow Vol. 85 pp. 298-313 (July 2016). DOI: 10.1016/j. ijmultiphaseflow.2016.06.018

2. Shintaro Takeuchi, Takaaki Tsutsumi, Katsuya Kondo, Takeshi Harada and Takeo Kajishima, "Heat transfer in natural convection with finitesized particles considering thermal conductance due to inter-particle contacts", Computational Thermal Sciences Vol. 7, Issue 5-6, pp. 385-404 (2015, Available online on 28 Jun., 2016). DOI: 10.1615/ComputThermalScien.2016014791
Horinouchi, N., "A consistent direct discretization scheme on Cartesian grids for convective and conjugate heat transfer", Journal of Computational Physics Vol. 321, pp. 76-104 (15 September 2016).

[5] Takagi, D., Takeuchi, S. and Kajishima, T., "Role of Vortical Structures on the Forced Convective Heat Transfer in Oscillation-Controlled Coaxial-Pipe Heat Exchanger", Journal of Enhanced Heat Transfer Vol. 22(5), pp. 365-389 (2015, Available online on 12 May, 2016).

[6] Fukada, T., Takeuchi, S. and Kajishima, T., "Wake structures of a particle in straight and curved flows", Springer Proceedings in Physics Ser Vol. 185 Proceedings of the 5th International Conference on Jets, Wakes and Separated Flows (ICJWSF2015), Ed: Antonio Segalini, pp. 189-194 (July 2016).

[7] 深田, 竹内, 梶島, “粒子周りの曲がった背景流 れに扮ける流体力の自己相似性”, ながれ Vol. 345, pp. 345-348 (2015).

\section{口頭発表}

1. Shintaro Takeuchi, "Numerical simulation of heat transfer in solid-dispersed two-phase media” (no paper), Invited talk at 2nd International Workshop on Numerical Simulations of Particle/ Droplet/Bubble-laden Flow, JAMSTEC Yokohama Institute, Yokohama, 13 October, 2016.

2. Jingchen Gu, Shintaro Takeuchi and Takeo Kajishima, "Effects of Solid Particles on Heat Transfer in Dense Particle-Liquid Two-Phase Media Based on Rayleigh Number", Two-phase Modelling for Sediment Dynamics in Geophysical Flows (THESIS 2016), Tokyo Japan, 12-14, September, 2016.

3. Jingchen Gu, Katsuya Kondo, Shintaro Takeuchi and Takeo Kajishima, "Direct Numerical Simulation of Heat Transfer in Dense ParticleLiquid Two-Phase Media”, International Conference on Multiphase Flow (ICMF 2016), Ref. No.: 517, Firenze, Italy, 22-27 May, 2016.

4. Toshiaki Fukada, Shintaro Takeuchi and Takeo 
Kajishima, "Volume-averaged equations for direct numerical simulation of particle-dispersed flow under a grid resolution comparable to particle diameter and Kolmogorov length scale", International Conference on Multiphase Flow (ICMF 2016), Ref. No.: 512, Firenze, Italy, 2227 May, 2016.

5. Shintaro Takeuchi, Suguru Miyauchi and Takeo Kajishima, "Mass transfer of solute and solvent across a deforming permeable membrane", International Conference on Multiphase Flow (ICMF 2016), Ref. No.: 337, Firenze, Italy, 2227 May, 2016.

6. Takeshi Harada, Shintaro Takeuchi and Takeo Kajishima, "Computational study of heat transfer in particle-laden flow considering temperature gradient within particles and inter-particle lubrication", Asian Symposium on Computational Heat Transfer and Fluid Flow 2015 (ASCHT 2015), Paper No.: 2015-KSCFE-452, Busan, Korea, 22-24 November, 2015.

7. Takeo Kajishima and Shintaro Takeuchi, "Direct numerical simulation of heat transfer in liquidsolid two-phase media" (peer reviewed), Invited talk at 7th European-Japanese Two-Phase Flow Group Meeting, Zermatt, Switzerland, 11-15 October 2015.

8. Takeo Kajishima, Katsuya Kondo, Shintaro
Takeuchi, "Numerical simulation of heat transfer in shear flow of liquid-solid two-phase media by immersed solid approach" (peer reviewed), ASME-JSME-KSME Joint Conference on Fluids Engineering 2015 (AJK2015-FED), Paper No.: AJK2015-07513 Seoul, Korea, 26-31 July, 2015.

9. Takanori Hanawa, Suguru Miyauchi, Shintaro Takeuchi and Takeo Kajishima, "DNS analysis of the interaction between turbulent flow and elastic fibers implanted on a flat plate" (peer reviewed), Ninth International symposium on turbulence and shear flow phenomena (TSFP-9) Melbourne, Australia, June 30-July 3, 2015.

10. Toshiaki Fukada, Shintaro Takeuchi and Takeo Kajishima, "Deflection of the wake of a particle in sheared ambient flows" (peer reviewed), International Conference on Jets, Wakes and Separated Flows (ICJWSF 2015) Stockholm, Sweden, June 16-18, 2015.

11. Shintaro Takeuchi, Takaaki Tsutsumi and Takeo Kajishima, "Heat transfer in particle-dispersed two phase flows considering temperature gradient within the particles" (peer reviewed), 6th International Symposium on Advances in Computational Heat Transfer, Paper No. CHT15-061, Piscataway, New Jersey, USA, 25-29 May, 2015. 